\title{
Analysis of Factors Affecting Islamic Insurance Profitability (Case Study Of Sinar Mas Islamic Insurance Period 2011-2017)
}

\author{
Siti Nurbaya ${ }^{1}$ and Azhar Alam ${ }^{2}$, \\ ${ }^{1}$ Faculty of Islamic Studies, Universitas Muhammadiyah \\ Surakarta \\ email: aya.elmudza@gmail.com \\ ${ }^{2}$ Faculty of Islamic Studies, Universitas Muhammadiyah \\ Surakarta \\ email: aa123@ums.ac.id
}

\begin{abstract}
Profitability is one benchmark to show a company operational performance. Various factors influence the amount of profitability. This research aims to analyze the influence of the amount of premium income, total investment, claims expense and operational costs on the profitability gained during the period 2011-2017. This paper conducts multiple linear analysis, namely OLS (Ordinary Least Square) with secondary data in the form of time-series data. The results of the t-test indicate that the claims expense variable has a negative and significant effect. Meanwhile, the operational cost variable has a positive and significant impact. On the contrary, the premium variable and the amount of investment both have a positive but not significant effect. Moreover, the results of the $\mathrm{F}$ test show that the variables of premium, investment, claims expense and operating costs have a considerable impact on the profitability of Sinar Mas Islamic Insurance.
\end{abstract}

Keywords: Islamic Insurance, premium, claims expense, operational cost, profitability

\section{INTRODUCTION}

As a country with Moslem majority, the existence of financial institutions following Islamic principles is urgently needed, 
including Islamic Insurance. The presence of Islamic Insurance is potentially able to attract the interest of Muslim communities. This because it can reach the public need for confident risk management based on the principles of Islamic law (Damayanti and Mawardi, 2015). Insurance is a financial institution that aims to form a social gathering to alleviate the individual's financial burden and avoid financing difficulties. In general, the concept of insurance is a preparation made by a group of people whom each face small losses as an unpredictable one.

Insurance is an agreement in which there is an agreement from the party that guarantees to the insured party, to receive some premiums instead of losses that might be suffered by the guaranteed, because of the consequences of the event (Purnomo, 2017). Existence of Law no. 40 of 2013 as a form of government attention to the Islamic insurance industry. Supervision of Islamic Non-Bank Financial Industry (IKNB) through OJK, one of which is Islamic insurance. According to Law no. 40 of 2013 Islamic Insurance is a collection of agreements, which consist of agreements between Islamic insurance companies and policyholders and arrangements between policyholders, to manage contributions based on Islamic principles to help and protect each other (Mariana, 2016). The operational system of Syariah Insurance (takaful) is mutually responsible, helpinghelping and protecting each other among the participants. Islamic Insurance Companies are given trust or trust by the participants to manage premiums, develop a halal way and provide compensation to those who experience disaster according to the agreement deed (Sula, 2016: 176).

As the global Islamic economic development began to increase, currently, the development of Islamic-based business activities and financial institutions (banks, insurance, capital markets, pawnshops, pension funds, etc.) is growing. In the last three decades, this institution can increase the volume and value of Islamic-based. Until the period of January 2016, the development of financial institutions based on Islamic Insurance grew significantly. The growth can be seen in Table 1 below, the 
increase in Islamic Insurance financial institutions from 2015 to the beginning of 2016 has increased according to Bank Indonesia data (Meiliana, 2015).

Table 1. Number of Islamic Insurance and Reinsurance Company and Unit Period 2015-2016

\begin{tabular}{clcc}
\hline No & Type of Insurance & $\mathbf{2 0 1 5}$ & $\mathbf{2 0 1 6}$ \\
\hline 1 & General Islamic Life Insurance & 3 & 5 \\
2 & General Islamic Insurance & 2 & 4 \\
3 & Units of Islamic General Life Insurance & 18 & 19 \\
4 & Units of General Islamic Insurance & 23 & 24 \\
5 & Units of Islamic Reinsurance & 3 & 3 \\
& Total & $\mathbf{4 9}$ & $\mathbf{5 5}$ \\
\hline
\end{tabular}

Source: www.bi.go.id

With the enormous potential of this sharia product, many insurance companies in Indonesia offer sharia products. The growth of the Sharia Insurance industry is targeted at 35\% per year. Even the latest data from the Financial Services Authority $(\mathrm{OJK})$, recorded growth in the total assets of Islamic Insurance companies until June 2015 amounted to $24.06 \%$. The placement of investment funds managed by Islamic insurance also increased by $27.59 \%$ while the contribution of Islamic premiums rose by 15.59\% compared to the period in 2013 (Ramadhani, 2015).

Islamic insurance in Indonesia is a prospective business opportunity because it suits with the development towards political and economic stability, with a population of more than 180 million people, Indonesia is one of the countries with the potentiality for investment by foreign investors. The fact that around $90 \%$ of the population is Muslim and the awareness to express their Muslim culture is increasing and has become a potential market share. For example, efforts in the field of halal labelled food and beverage, Muslim clothing and accessories, pilgrimage, umrah, education and Islamic publications, all of these have increased rapidly in the last 15 years (Ichsan, 2016). 
The success of a company can be measured by looking at a company's ability to earn profits, profits or profits can be defined in two ways, gain with a real economy is defined as an increase in an investor's wealth as a result of capital investment, after deducting costs associated with the venture. Meanwhile, profit in accounting is defined as the difference between sales prices and production costs. Operational profit is defined as the difference between realized revenues arising from transactions during one period with related costs (Belkaoui, 2006).

This research is essential, considering that profitability is the benchmark of a company in carrying out its operations to the fullest. With a high level of profitability shows that the company can optimize its assets well, so that profitability is the basis for management to decide whether the company's system will be maintained or improved, and maintain public trust in the potential of Islamic insurance companies.

\section{LITERATURE REVIEW Definition of Islamic Insurance}

In Article 246 of the Indonesian Commercial Law Act, it is explained that insurance is an agreement in which an insurer binds himself to an insured with a premium that provides compensation for him due to a loss, damage and calamity he suffered, which suffered because of something he did not certainly (Ali, 2008). Sula (2016) defined insurance is a way or method to protect and avoid risk or danger that is furious that can happen anytime and anywhere in everyday activities.

Islamic insurance according to the National Sharia Council of the Indonesian Ulema Council (DSN-MUI) NO: 21 / DSNMUI / X / 2001 is described as an effort to protect each other and help between a number of people or parties through investments in assets and / or tabarru 'which provide a pattern of returns to deal with specific risks through a sharia-compliant agreement.

Islamic insurance has several equivalent words, namely taka $>$ ful, tami $>$ n dan $\operatorname{tad}\{a>$ mun, which has the meaning of bearing and helping each other. So that insurance is mutually protective, and help is called ta'awun, which is the principle 
of mutual protection and improve based on ukhuwah among members of Sharia insurance participants in the face of risk. Thus the insurance company is only limited to the operational manager of the insurance company and investment funds received from the insured party to the company as guarantor (Ali, 2008).

\section{The Concept of Profitability in Islamic Insurance}

At present, the national bank's alignment with the agricultural sector is very low. Based on BI data, domestic bank lending as of March 2007, only 5.4 per cent of total loans amounted to 800.337 billion. Furthermore, credit is dominated by the services sector by 37.21 per cent, industrial sector 22.93 per cent, trade 20.93 per cent. Therefore, the role of Islamic banking is expected to drive the agricultural sector in Indonesia. Profitability is the ability of a company to earn profits concerning sales, total assets, as well as its model or an overview of management's performance in managing the company.

Profitability shows the ability of the model invested in all assets to generate profits for investors, namely the extent of the effectiveness of all management in creating benefits for the company (Patriana, 2014). Safitri (2015) stated the higher the level of profitability the better for the company itself. The higher the level of profitability of a company, the greater the level of prosperity provided by the company, so that it will be more attractive to many investors, and will have a positive impact and increase the value of the company. There are several ratios used to measure profitability, namely:

1. Return on Assets (ROA)

ROA is usually referred to as the return on assets, which shows how much the asset contributes to generating net income, and this ratio is the ratio between net income and total assets or assets.

2. Return on Investments (ROI)

This ratio is the ratio between net income and total investment, where the percentage of this receipt 


\section{Return on Equity (ROE)}

The return on equity is a ratio that shows the amount of equity contribution in creating net income, and this ratio shows the efficiency of the use of its model, which can be calculated by dividing net income with total equity.

In the Insurance industry, there are several variables to determine its performance by managing these factors :

1. Amount of Premium

Premium is a payment of a sum of money made by the insured party to the insurer to replace a loss, damage or loss due to the emergence of an agreement for the transfer of risk from the insured to the insurer. The premium amount is determined from the results of risk selection carried out by the underwriter or after the company carries out risk selection at the request of the insured fund. Thus the prospective insured will pay insurance premiums according to the level of risk or their respective conditions (Amrin, 2006).

2. Amount of Investment

Investment is one of the supporting components of Sharia insurance growth. Investment is to invest or place assets in the form of funds or assets in a manner that is expected to provide income results or will increase its value in the future. Investment can also be interpreted as a component of aggregate expenditure after consumption. Investments sourced from public funds collected through financial and non-financial institutions are then channelled to institutions or companies, and the investment funds are invested by related parties to obtain profits.

3. Number of Claims

Claims are processes in which participants can get coverage for losses available under the agreement. All efforts given to ensure these rights are fully respected as they should be. Therefore it is crucial for sharia insurance managers to handle claims efficiently. In resolving complaints in the form of 
damage or loss, the insurance company refers to the contract and the agreement written in the policy. The procedure in determining both Takaful and conventional insurance is almost the same, except in terms of speed and honesty in assessing claims(Sula, 2016).

4. Operational Costs

Cost is the amount measured in money from cash issued or other property transferred, share capital issued, services provided, or obligations that occur about goods or services that have been or will be received. Operating expenses (operating expansion) are costs in the form of spending money to carry out necessary activities, namely in the way of sales and administrative costs to obtain income that supports operations or activities carried out by the company (Belkaoui, 2006).

\section{Previous Research}

Some studies found that the claim and investment variables had a significant effect on profitability in Islamic Insurance, while the premium and profit variables have no significant impact on it. Other studies found that the premium variable, claim investment and underwriting has a substantial impact on corporate insurance earnings.

The research conducted by Ashal (2006) about the position of the tijarah and tabarru contract in Sharia insurance obtained results that the concept of Multi contract in Sharia insurance aims to stay away from usury, gharar and maisir. The double contract contained in insurance is not a thermal contract that is prohibited following the hadith of the Prophet. The contract provided in Sharia insurance is an agreement that is takaful, bearing each other's burden and help.

\section{Hypothesis}

Based on the discussion of various theories and previous research, the following hypotheses are formulated:

1. The amount of premium has a positive influence on the profitability of Sinar Mas Syariah Insurance for the period 
2011-2017.

2. The amount of investment has a positive influence on the profitability of Sinar Mas Syariah Insurance for the period 2011-2017.

3. Claim expenses have a negative influence on the profitability of Sinar Mas Syariah Insurance for the period 2011-2017.

Operational costs have a positive influence on the profitability of Sinar Mas Syariah Insurance for the period 2011-2017.

\section{METHODS}

\section{Analysis of Tools and Econometric Model}

The tools and analysts used in this study are OLS (Ordinary Least Square) model regression analysis. The econometric model used is as follows:

LOG (Profit) $t=\beta 0+\beta 1$ LOG (PRE) $t+\beta 2$ LOG (INV) $t+\beta 3$ LOG $(\mathrm{BKL}) \mathrm{t}+\beta 4 \mathrm{LOG}(\mathrm{BOP}) \mathrm{t}+\varepsilon \mathrm{t}$

Note: $\beta 0=$ Constants, $\beta 1 \beta 2 \beta 3=$ Regression coefficient, $\mathrm{PRE}=$ Amount of premium, INV $=$ Amount of investment, $\mathrm{BKL}=\mathrm{Claim}$ expense, $\mathrm{BOP}=$ Operational costs, $\varepsilon=$ error element, and $\mathrm{t}=$ year The estimation of the regression model includes several stages, namely: parameter estimation of econometric models; classic assumption testing consisting of multicollinearity test, residual normality test, autocorrelation test, heteroscedasticity test, model specification test, model goodness test, and validity test of influence. Model goodness test will include a model existence test ( $F$ test), and coefficient of determination $\mathrm{R} 2$; and effect validity test (t-test).

\section{OLS Regression Model (Ordinary Least Square)}

This study used OLS Regression Model (Ordinary Least Square) to analyze the data. Regression analysis is a study of the dependence of a dependent variable with one or more independent variables, to estimate or predict the average population or the average expansion of the dependent variable based on the value 
of the known independent variable. The focus of analysis is to explain and evaluate the relationship between a variable with one or more independent variables (Kuncoro, 2009).

The OLS method or the smallest quadrant method is the most commonly used. According to the Gauss-Markov theorem based on assumptions from classical linear regression, OLS estimation has the lowest variance among other linear estimators, in this case, the OLS estimator is called the Best linear unbiased estimator BLUE Using assumptions certain, the OLS method has interesting statistical properties that make it the most robust approach. OLS estimators have the following features (Gujarati, 2008).

\section{Classic Assumption Test}

\section{Multicollinearity Test}

The term multicollinearity means that there is a definite linear relationship between several independent variables from multiple regression models. Then the term multicollinearity is interpreted more broadly, namely the occurrence of high direct correlation among explanatory variables. Problem multicollinearity often appears in the econometric model because economic variables are interrelated (Kusrini, 2010).

\section{Residual Normality Test}

The normality test aims to test whether, in the regression model, the residual has a normal distribution. As it is known that the $\mathrm{t}$-test and $\mathrm{F}$ test assume the residual value follows a normal distribution. If this assumption is violated, the statistical test becomes invalid for a small number of samples. The test is used to detect whether the residual has a normal distribution or not by using graph analysis and statistical tests (Ghozali, 2011).

\section{Heteroscedasticity Test}

Heteroscedasticity occurs when the variation of the ut changes systematically as the value of the independent variable changes. The consequence of the existence of heteroscedasticity is that regression analysis will produce an estimator that is biased 
for the variation value of ut. As a result, the $F$ test $t$ and the estimated dependent variable costs are invalid (Gujarati, 2003).

\section{Model Specification and Model Goodness Fit Test}

This paper conducted a model specification test to test the linearity assumption of the model, so it is often called the linearity test model. The test used here is the Ramsey Reset test or also called the general specification error test.

This paper uses the F statistical analysis. The F statistical test shows whether all the independent variables included in the model have a joint or simultaneous influence on the dependent variable. The null hypothesis is the Joint hypothesis that $\beta 1, \beta 2 \ldots$ $\beta \mathrm{k}$ simultaneously equals zero (Ghozali, 2011).

The coefficient of determination (R2) is used to determine the extent to which the accuracy of the regression lines formed in representing groups of observational data. The coefficient of determination describes a part of the total variation that can be explained by the model. The higher the value of R2 (close to 1) then the accuracy is said to be better, in general, the coefficient of determination for cross-data is relatively low because of the significant variations between each observation, while for time series data usually has a coefficient value (Ghozali, 2011).

This study also used The $\mathrm{t}$ statistical test to demonstrate how far the influence of one independent variable on the dependent variable by assuming the other independent variables is constant. The t-test is used for partial significance testing (Utomo, 2015).

\section{Type and Sources of Data}

This study examined two variables, the dependent variable and the independent variable. The dependent variable used in this study is the profitability of Islamic insurance. This profit calculation is derived from the income variable and the insurance cost or expense variable, profitability is the company's ability to generate or earn profits. This profitability analyst describes the company's performance in terms of the level of efficiency and effectiveness of the company's operations in obtaining benefits. 
The independent variables used in this study are four variables. First, the premium amount which is defined by payment of a sum of money paid by the insured party to the insurer. Second, investment of a certain amount of funds at this time to obtain gain in the future. Third, claim as the application of participants to get coverage for their agreed losses based on the agreement or the process of submission by insurance participants to obtain rights and coverage after the participant has fulfilled his obligations under the contract. Fourth, operational costs that must be incurred by the company to run the insurance company.

This research used secondary data in the form of time series data with the period 2011-2017. The data was obtained from the financial statements of PT. Sinar Mas Syariah Insurance that has been published by the relevant agencies. The used data are the number of premiums, the amount of investment, claims expense and operational cost.

\section{RESULTS AND DISCUSSION \\ The Description of Sinar Mas Islamic Insurance}

The Islamic-based business activities and financial institutions in Indonesia are overgrowing; one of them is Sinar Mas Islamic Insurance. With the majority of Moslems in Indonesia, Islamic financial institutions possibly get huge market potential. In 2004 Sinar Mas Insurance developed Islamic products, using the concept of helping in kindness and loyalty and stipulating contracts that are under Islamic law which do not contain Gharar (uncertainty), Maysir (gambling), usury (interest), illicit goods and immorality because those re prohibited in Islamic financial contracts. Sinar Mas Islamic Insurance is one of the largest general insurance companies in Indonesia. Throughout the journey, Sinar Mas Insurance shows continuous growth. The gross premiums and total assets of the company consistently increase from year to year, as well as services to its customers through quick and precise claim payments.

\section{The Estimation Results}

In this study to analyze the effect of the amount of premiums, 
the amount of investment, the claim burden and operational costs on profitability this research used the Ordinary Least Square (OLS) regression analysis with the result as follows:

Table 2. Result of Econometric Model Estimation

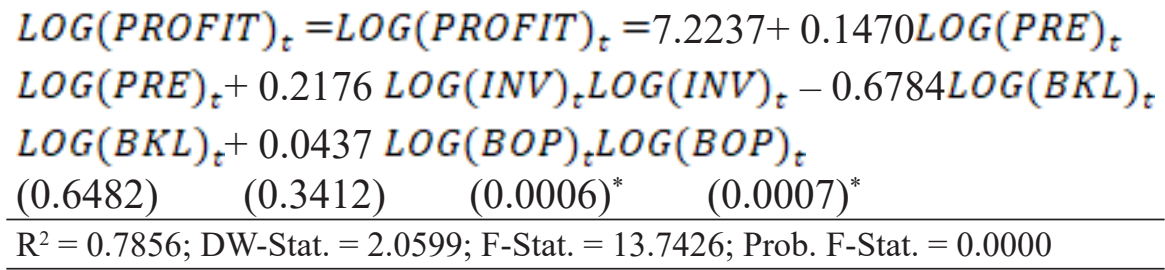

Diagnosis Test

(1) Multicollinearity (VIF)

$\mathrm{PRE}=1.9808 ; \mathrm{INV}=2.0739 ; \mathrm{BKL}=1.5878 ; \mathrm{BOP}=3.3619$

(2) Normality

$\mathrm{JB}=0.8353$; Prob. $(\mathrm{JB})=0.6585$

(3) Autocorrelation(Bruesch Godfrey)

$\chi^{2}=1.8414 ;$ Prob. $\left(\chi^{2}\right)=0.6060$

(4) Heterocedasticity (white)

$\chi^{2}=6.9535 ;$ Prob. $\left(\chi^{2}\right)=0.5417$

(5) Linearity (Ramsey Reset)

$\mathrm{F}=1.3336$; Prob. $(\mathrm{F})=0.2976$

Source: BPS data organized. Note: ${ }^{*}$ Significance pada $a=0,01$;

${ }^{* *}$ Significance pada a $=0,05 ;{ }^{* * *}$ Significant at a $=0,10$. The number in parentheses is the empirical ( $p$-value) probability of t-statistics.

\section{Classic Assumption Test}

This study used time series data and acquired the classic assumption including multicollinearity test, residential normality test, autocorrelation test, heteroscedasticity test and model specification test.

\section{Multicollinearity Test}

The multicollinearity test in this study is the Variance Inflation Factor (VIF) test. If the VIF value is $>10$, there is a multicollinearity problem, but if the VIF value is $<10$, there is no multicollinearity problem in the model. VIF test results can be seen in Table 3 below : 
Table 3. Result of VIF Test

\begin{tabular}{cccc}
\hline Variabel & VIF & Criteria & Conclusion \\
\hline PRE & 1.9808 & $<10$ & Does not cause multicollinearity \\
INV & 2.0739 & $<10$ & Does not cause multicollinearity \\
BKL & 1.5871 & $<10$ & Does not cause multicollinearity \\
BOP & 3.3619 & $<10$ & Does not cause multicollinearity \\
\hline
\end{tabular}

Table 3 demonstrates that each of variable does not cause multicollinearity. It means that data fulfill classic assumption in multicollinearity.

\section{Residual Normality Test}

The normality test used in this study is the linear test with hypothesis formulation $\mathrm{H} 0$ : Utnormal distribution and $\mathrm{HA}$ : Ut distributions are not normal, with the $\mathrm{H} 0$ test criteria accepted if the $\mathrm{JB}>\alpha$ and $\mathrm{H} 0$ probability statistics are rejected if the $\mathrm{JB}<\alpha$ probability statistics are rejected.

From table 2, it can be seen that the probability of a quarrel value is $0.6585(>0.01)$, then $\mathrm{H} 0$ is accepted, so the Ut distribution is normal.

\section{Autocorrelation Test}

The autocorrelation test used in this study is the Breuschodfrey test with hypothesis formulation $\mathrm{H} 0$ : there is no problem of autocorrelation in the model and HA: there is an autocorrelation problem in the model, with the testing criteria. H0 is accepted if the empirical significance of statistics $c 2$ BG test $>\alpha$ and $\mathrm{H} 0$ are rejected if the practical significance of the statistics $c 2$ BG test $£$ $\alpha$.

Table 2 shows there is a probability value or statistical, empirical significance - test BG at $0.6060(>0.10)$. Then, $\mathrm{H} 0$ is accepted by the conclusion that there is no autocorrelation in the model.

\section{Heteroscedasticity Test}

Heteroscedasticity test in this study used the White test with the hypothesis formulation, namely $\mathrm{H} 0$ means there is no 
problem of heteroscedasticity and the HA model that means there is heteroscedasticity problem. In the model. Criteria estimation is described by $\mathrm{H} 0$ is accepted if the empirical significance of statistics $c 2$ test $\mathrm{BG}>\alpha$ and $\mathrm{H} 0$ is rejected if the practical significance of the statistics $c 2$ test $\mathrm{BG} £ \alpha$.

From table 2 the probability value or empirical significance of statistics is known as statistic $c 2$ about $0.5417(>0.10)$, so $\mathrm{H} 0$ is accepted by the conclusion that there is no problem of heteroscedasticity in the model.

\section{Model Specifications Test}

The model specification test used in this study is the Ramsey reset trial with hypothesis formulation $\mathrm{H} 0$ : linear model (exact model specification) and HA: the model is not linear (the model specification is incorrect), with criteria estimation namely $\mathrm{HO}$ is accepted if the probability statistics $\mathrm{F}>\alpha$ and $\mathrm{H} 0$ is rejected if the probability statistic $\mathrm{F}<\alpha$.

From Table 2, it is known that the probability value $\mathrm{F}$ of Ramsey is equal to $0.2976(>0.10)$, so then $\mathrm{H} 0$ is accepted and declares the exact model specification (linear model).

\section{Model Existence Test (F)}

The existence test in this study used the $\mathrm{F}$ test with hypothesis formulation $H 0: \beta 1=\beta 2=\ldots=\beta n=0$ means the used model does not exist and $H A: \beta 1 \neq \beta 2 \neq \ldots \neq \beta n \neq 0$ means the used exists, with the criteria estimation the $\mathrm{H} 0$ test is accepted if the statistical significance of $\mathrm{F}>\alpha$ and $\mathrm{H} 0$ is rejected if the statistical significance of $\mathrm{F}<\alpha$. Table 2 illustrates that the significance value of $\mathrm{F}$ is $0.000(<0.01)$, so then $\mathrm{H} 0$ is rejected and as a consequence the used model exists.

\section{Interpretation of the Determination Coefficient (R2)}

Based on Table 2 the estimation results show the $\mathrm{R} 2$ value is 0.7856 , which means that $78.56 \%$ of the variable profit variation can be explained by the variable premium, total investment, claim expense and operating costs, while the remaining 21.44 is explained by other variables not included in the model. 


\section{Effect Validity Test (t Test)}

The t-test is used to determine the magnitude of the influence of each independent variable on the dependent variable partially. If the probability is $t>\alpha$, then variable has a significant effect. The results of the t-test can be seen in table below:

Table 4. Validity Test Results of Independent Variabel Effects

\begin{tabular}{llrl}
\hline Variable & sig. T & Criteria & Conclusion \\
\hline PRE & 0.6482 & $>0.10$ & Not significant at $\alpha=0.10$ \\
INV & 0.3412 & $>0.10$ & Not significant at $\alpha=0.10$ \\
& & & Significant at $\alpha=0.01$ \\
BKL & 0.0006 & $\leq 0.01$ & Significant at $\alpha=0.01$ \\
BOP & 0.0007 &
\end{tabular}

Table 4 shows that two of four independent variable have significant influence on the Islamic Insurance profitability.

\section{Interpretation of Independent Variable Effects}

From the validity test of the influence it shows that the variables that have a significant effect are the claim burden and operational costs. While the variable amount of premiums and the amount of investment has no significant influence. Variable burden of Sinar Mas Islamic insurance claims in Indonesia has a regression coefficient of -0.678442 . The pattern of the relationship between insurance profitability and claim expense is logarithm-logarithms, meaning that if the claim burden rises by one thousand rupiah, the insurance profitability will decrease by $67.84 \%$. Conversely, if the claim expense drops by one thousand rupiah, profitability will increase by $67.84 \%$. The operating cost variable in Sinar Mas Islamic Insurance in Indonesia has a regression coefficient of 0.0437 . The pattern of the relationship between insurance profitability and operational costs is logarithms-logarithms, meaning that if the operational costs increase by one thousand rupiahs then the insurance profitability will increase by $4.37 \%$. Conversely, if operating costs fall, profitability will decrease by $4.37 \%$. The rise and fall of the profitability of operational costs here is in the form of increased assets owned by insurance companies such as office equipment and supplies. 


\section{Economic Interpretation}

Based on the results of the research, the results of variable claim costs and operational costs are significant, meaning that even though insurance gets a large amount of income, if the amount of claim expenses and operational costs is also large, it will result in little net income income processing. The results of this study are in accordance with the research conducted by Ainul (2016) which states that the claim burden has a negative effect and operational costs have a positive effect, so that a large number of the two variables with large income also shows that the insurance company is growing well with good corporate performance. Healthy growth is considered as a basic requirement of the success of the company that has the opportunity to increase market share and attract investors to invest their funds in Sharia Insurance companies.

Insurance as a protection system for the risks faced by society from financial losses requires professionalism from the insurance company that manages it. That is by keeping the finances in such a way that they can give high trust to the community.

\section{CONCLUSION}

Based on the results of the OLS (OrdinaryLeast Square) model analysis that was carried out this paper conclude that the claim fund variable in this study has a negative effect and operational costs have a positive influence which are both significant to the profitability of Sinar Mas Islamic Insurance. The premium variable and the amount of investment do not have a significant influence on the profitability of Sinar Mas Syariah Insurance in the period 2011-2017. This paper used classic assumption test and it shows that all models meet classic assumptions, meaning that regression results can be used as a conclusion tool.

High claims costs and operational costs can have an impact on the ability to maintain company finances which later can be considered by the community to join insurance companies, as well as investors who will invest their funds in Sharia Insurance companies, and have the opportunity to encourage economic growth. 
Further researchers would better add other variables that can affect the profitability of Islamic insurance, so that it can provide better research results. This is because there are few research variables. As well as the expected use of different measurements in seeking profitability efficiency. The investment ratio does not significantly affect the profitability of Islamic. However, this investment activity must be fully supported by the government, so as to encourage investors to invest their capital in Sharia Insurance Companies, which in turn will support economic growth.

\section{REFERENCE}

Ali, Z. (2008) Hukum Asuransi Syariah. Jakarta: Sinar Grafika.

Amrin, A. (2006) Asuransi Syariah. Jakarta: PT Alex Media Komputindo.

Ashal, F. F. (2006) 'Kedudukan Akad Tijarah dan AKad Tabarru' Dalam Asuransi Syariah', Human Falah, pp. 239-252.

Belkaoui, A. R. (2006) Teori Akuntansi. Jakarta: Salemba Empat. Damayanti, F. E. and Mawardi, I. (2015) 'Analisis faktor-faktor yang mempengaruhi surplus undewriting asuransi umum syariah di indonesia', Jurnal Ekonomi Syari'ah Teori dan Terapan., 4.

Ghozali, I. (2011) Ekonometrika Teori Konsep dan Aplikasi dengan SPSS 17. Semarang: Universitas Diponegoro.

Gujarati, D. N. (2003) Basic Econometric. Singapore: McGrawwHill Companies.

Gujarati, D. N. (2008) Dasar-Dasar Ekonometrika. Jakarta: Erlangga.

Hartono, S. R. (1992) Hukum Asuransi dan Perusahaan Asuransi. Jakarta: Sinar Grafika.

Kuncoro, M. (2009) Metode Riset Untuk Bisnis Dan Ekonomi. Jakarta: Erlangga.

Patriana, E. (2014) 'Model Perhitungan Tarif Premi Asuransi Syariah Dalam Hubungan Segmentasi Pasar dan Laba Perusahaan', Jurnal Etikonomi, 03(02). 
Safitri, A. W. N. (2015) 'Pengaruh Struktur Model dan Keputusan Investasi Terhadap Profitabilitas dan Nilai Perusahaan', Jurnal Ilmu dan Riset Manajemen., 4(2).

Sula, M. S. (2016) Asuransi Syariah (Life and General) : Konsep dan Sistem Oprasional. Jakarta: Gema Insani Press.

Utomo, Y. P. (2015) Ekploitasi Data dan Analisis Regresi dengan SPSS. Surakarta: Fakultas Ekonomi dan Bisnis Universitas Muhammadiyah Surakarta. 